\title{
Діагностичні критерії прогнозування можливих ускладнень у хворих із хронічним калькульозним холециститом та супутньою патологіею вен нижніх кінцівок
}

\begin{abstract}
Мета роботи: дослідити стан гомеостазу організму під час і після виконання малоінвазивних операційних втручань, що дозволить виробити патогенетично обгрунтовану корекцію можливих порушень.

Матеріали і методи. Хворим із хронічним калькульозним холециститом та патологією вен нижніх кінцівок у доопераційний період проводили комплекс діагностичних інструментально-лабораторних методів обстежень, який включає лабораторні обстеження 3 біохімічним аналізом крові, сонографію панкреатогепатобіліарної зони і заочеревинного простору та фіброгастродуоденоскопію. Для об’єктивної оцінки стану гомеостазу оцінювали показники у кожного хворого, а потім визначався сумарний результат.

Результати досліджень та їх обговорення. Встановлено, що клініка холециститу супроводжується вираженим поліморфізмом, причому загальноприйняті індикатори запального процесу не збігаються із зареєстрованими патологічними змінами. На підставі результатів дослідження обгрунтовано доцільність застосування у післяопераційному періоді у хворих після ЛХЕ тривалістю більше 90 хв коригувальної медикаментозної терапії.

У 26 хворих із 130 діагностували супутню патологію - варикозну хворобу вен нижніх кінцівок. Нами відмічено, що у пацієнтів, госпіталізованих у стаціонар із діагнозом хронічний калькульозний холецистит, при дуплексному скануванні вен нижніх кінцівок спостерігалось незначне розширення діаметра глибоких та поверхневих вен після проведення лапароскопічної холецистектомії. У хворих із супутньою патологією вен нижніх кінцівок у післяопераційному періоді отримані результати при дуплексному скануванні вен були найбільш виражені, що зумовило проведення як в передопераційному, так і в післяопераційному періоді відповідних заходів щодо профілактики тромбоемболічних ускладнень та виконання симультанних операційних втручань. Отримані результати підтвердили необхідність операційного втручання з приводу варикозної хвороби вен нижніх кінцівок у хворих із хронічним калькульозним холециститом, що необхідно з метою профілактики розвитку в післяопераційному періоді тромбозу, а відтак можливої в подальшому тромбоемболії легеневої артерії.
\end{abstract}

Ключові слова: холецистит; варикозна хвороба; симультанні втручання; клініко-інструментальні методи дослідження; дуплексне сканування вен.

Постановка проблеми і аналіз останніх досліджень та публікацій. Однією з актуальних проблем екстреної хірургії органів черевної порожнини $є$ лікування хворих з жовчнокам'яною хворобою. Більшість хворих із холециститом потрапляє в стаціонари в пізні терміни захворювання (до 80 \% хворих), а отже, у значної кількості пацієнтів наявні його ускладнені форми [2, 3, 4].

Лікувальна тактика при хронічному холециститі визначається тяжкістю стану пацієнтів, який, в свою чергу, залежить від наявності супутньої патології, віку, маси тіла хворого та ступеня виявлених порушень у лабораторно-інструментальних методах досліджень [1,9].

В останні роки збільшився інтерес до поєднаних (симультанних) операцій, якими є операційні втручання, що виконують одночасно на двох чи більше органах з приводу різних захворювань [5, 7, 8].

За даними деяких авторів [6], у 2-5 \% хворих, яким була виконана лапароскопічна холецистектомія з приводу жовчнокам'яної хвороби, протягом року проявляється патологія вен нижніх кінцівок.
Ця обставина вимагає ретельного обстеження хворих як перед операцією, так і після.

Матеріали і методи. Обстежено 130 хворих із приводу хронічного калькульозного холециститу. Хворі з хронічним калькульозним холециститом були прооперовані тільки після передопераційної інфузійної і протизапальної терапії та проведення комплексу діагностичних інструментально-лабораторних методів обстежень, яке включає лабораторні обстеження з біохімічним аналізом крові, сонографію панкреатогепатобіліарної зони i заочеревинного простору та фіброгастродуоденоскопію.

Операції з короткочасною передопераційною підготовкою, особливо у хворих старечого віку, виконували за показами, що не дозволяє повною мірою провести діагностичні заходи і корекцію супровідної патології, це призводило до більш тяжкого перебігу післяопераційного періоду. Крім цього, лапароскопічна холецистектомія у хворих 3 хронічним холециститом без адекватної передопераційної підготовки має ряд інтраопераційних 
технічних труднощів, пов'язаних 3 виділенням стінки жовчного міхура.

Тривала передопераційна медикаментозна підготовка поглиблює інтоксикацію, розлади білоксинтезуючої функції печінки, дискоординацію гуморального і клітинного імунітету. Покращення загального стану хворих під впливом консервативної терапії не є протипоказанням до операційного лікування.

Ступінь вираженості змін гомеостазу залежить від тривалості захворювання, характеру ускладнень хронічного калькульозного холециститу i способу операційного втручання. Для об’єктивної оцінки стану гомеостазу ми оцінювали показники у кожного хворого, а потім визначали сумарний результат. ЛХЕ викликає менш виражені порушення гомеостазу зі зменшенням термінів їхнього відновлення порівняно з традиційною холецистектомією (TXE).

Розробка нових способів операційного лікування поєднується з очевидною необхідністю вивчення стану гомеостазу організму під час і після виконання малоінвазивних операційних втручань, що дозволило виробити патогенетично обгрунтовану корекцію можливих порушень.

Результати досліджень та їх обговорення. Встановлено, що клініка холециститу супроводжується вираженим поліморфізмом, причому загальноприйняті індикатори запального процесу не збігаються із зареєстрованими патологічними змінами. На підставі результатів дослідження обгрунтовано доцільність застосування у післяопераційному періоді у хворих після ЛХЕ тривалістю більше 90 хв коригувальної медикаментозної терапії.

За допомогою УЗД визначали форму, розміри, розміщення, стан стінки, вміст жовчного міхура,

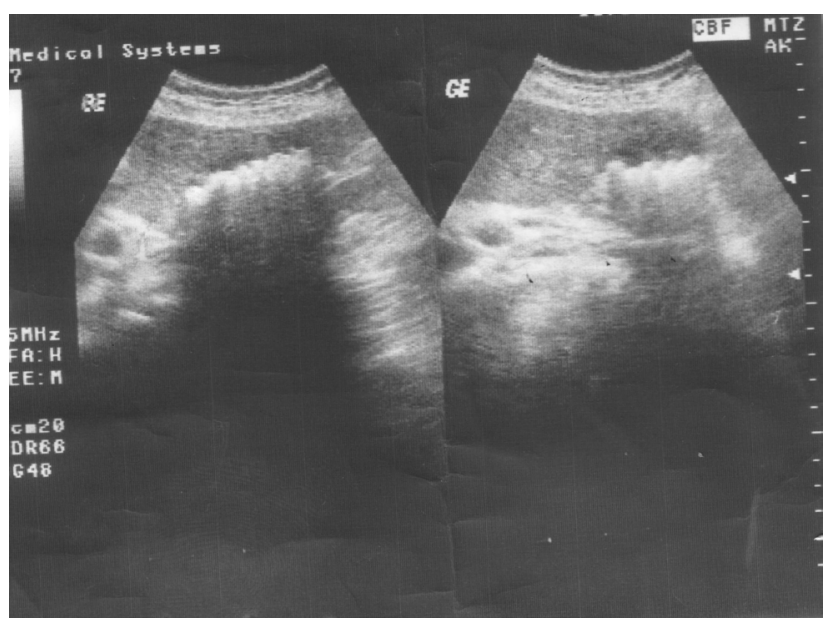

Рис. 1. УЗД жовчного міхура у хворого із конкрементом у шийці. при цьому звертали увагу на вираженість та ступінь запальних змін у ньому (наявність чи відсутність вогнищевих гіпоехогенних зон стінки жовчного міхура з переривом контуру; ехопрозорої смужки за передньою або задньою стінками жовчного міхура; наявність вільної рідини в підпечінковому просвіті та інших відділах черевної порожнини; подвоєння контуру стінки жовчного міхура 3 відшаруванням слизової в просвіті жовчного міхура; подвоєння контуру стінок жовчного міхура без відшарування слизової; товщини стінки жовчного міхура більше 3 мм; збільшеного жовчного міхура; відсутність візуалізації шийки жовчного міхура). Особливу увагу приділяли фіксованим гіперехогенним включенням у проекції шийки жовчного міхура або локалізації конкремента в шийці, розмірам конкрементів та їх міграції, діаметра загальної жовчної протоки, стану підшлункової залози, печінки, елементів гепато-дуоденальної зв'язки, інших сусідніх органів (рис. 1, 2).

У 26 хворих діагностували супутню патологію - варикозну хворобу вен нижніх кінцівок. Розширення підшкірних вен нижніх кінцівок спостерігали в основному у жінок (21 пацієнтка). Діагноз ХВН у хворих із варикозною хворобою встановлювали на основі класифікації, запропонованої В. С. Савельєвим, Е. Г. Яблоковим та А. І. Кірієнко (IX Міжнародний з’їзд хірургів, 2000 р.). При вивченні клініки захворювання визначали наявність розширення підшкірних вен, набряку, болю, гіперпігментації, ліподерматосклерозу, наявність чи відсутність трофічних виразок у стадії загоєння або активних.

Патофізіологію ХВН нижніх кінцівок вивчали на підставі визначення ступеня венозної недостатності за допомогою ультразвукового дуплексного сканування [10].

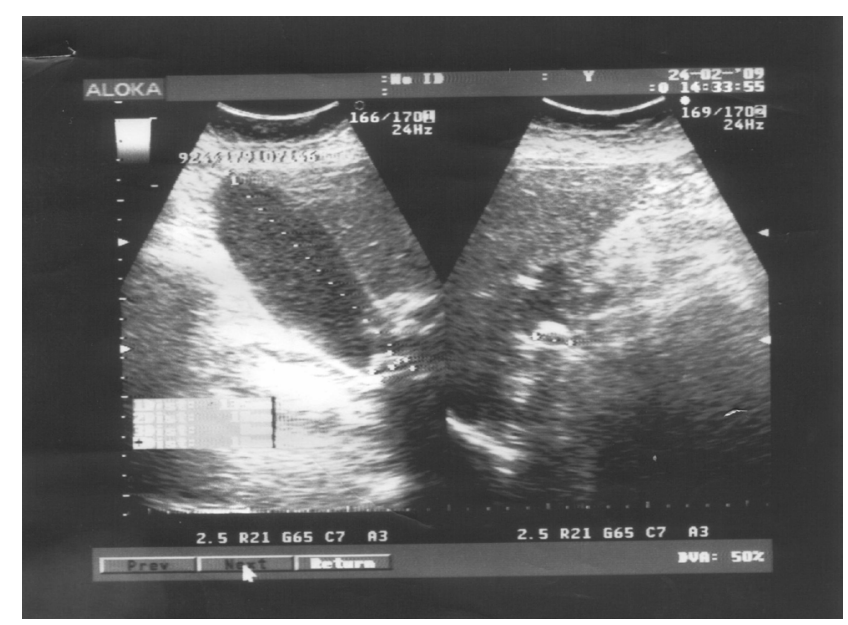

Рис. 2. УЗД жовчного міхура у хворого із множинними конкрементами. 
У передопераційному та післяопераційному періодах усім пацієнтам із варикозною хворобою вен нижніх кінцівок та 44 хворим на хронічний калькульозний холецистит було виконано ультразвукове дуплексне сканування вен нижніх кінцівок (табл. 1).

Встановлено, що у пацієнтів, госпіталізованих у стаціонар із діагнозом хронічний калькульозний холецистит, при дуплексному скануванні вен нижніх кінцівок спостерігалось незначне розширення діаметра глибоких та поверхневих вен після проведення лапароскопічної холецистектомії. У пацієнтів похилого віку (понад 60 років) розширення діаметра вен було значно більшим (до 5 \%).

У хворих із супутньою варикозною хворобою вен нижніх кінцівок у післяопераційному періоді дані отримані при дуплексному скануванні були найвищими і на 8 \% перевищували діаметр судин до операції (табл. 2).

Хворим із варикозною хворобою вен нижніх кінцівок визначали прохідність глибоких вен та стан клапанів; розташування та функцію остіальних клапанів великої та малої підшкірних вен; реф- люкс крові по стовбурі великої та малої підшкірних вен, подвоєння стовбура великої підшкірної вени; наявність неспроможних перфорантних вен. Місця локалізації неспроможних перфоратних вен позначали на шкірі розчином діамантової зелені.

Клінічний випадок. Хвора О., 58 років госпіталізована в стаціонар зі скаргами на наявність болю в правому підребер'ї з іррадіацією в праве плече, гіркоту в роті, підвищення температури тіла до $37,2{ }^{\circ} \mathrm{C}$, відчуття тяжкості в нижніх кінцівках, пастозність та наявність розширених вен у ділянці нижніх кінцівок. Вищеназвані симптоми періодично турбували протягом 3 років. Останні прояви захворювання з'явились 2 дні тому після порушення режиму харчування. Від варикозної хвороби вен страждає протягом 10 років, спадковий анамнез за хворобами поверхневих вен нижніх кінцівок обтяжений (мати хірургічно оздоровлена з приводу ВХВ).

При огляді загальний стан задовільний, шкірні покриви та видимі слизові блідо-рожевого кольору, чисті. Над легенями перкуторно ясний легеневий звук, аускультативно дихання везикуляр-

Таблиця 1. Показники діаметра вен нижніх кінцівок (мм) у хворих із хронічним калькульозним холециститом до та після ЛХЕ

\begin{tabular}{|c|c|c|c|c|c|c|}
\hline \multirow{3}{*}{ Обстежувана вена } & \multicolumn{6}{|c|}{ "Хронічний калькульозний холецистит } \\
\hline & \multicolumn{2}{|c|}{$\begin{array}{c}\text { молодий вік } \\
(18-44 \text { років) } \\
n-22\end{array}$} & \multicolumn{2}{|c|}{$\begin{array}{c}\text { середній вік } \\
(45-59 \text { років) } \\
\mathrm{n}-14 \\
\end{array}$} & \multicolumn{2}{|c|}{$\begin{array}{c}\text { похилий вік } \\
\text { (60 і більше років) } \\
\text { n - } 8\end{array}$} \\
\hline & до ЛХЕ & після ЛХЕ & до ЛХЕ & після ЛХЕ & до ЛХЕ & після ЛХЕ \\
\hline Загальна стегнова & $12,0 \pm 0,9$ & $\begin{array}{l}13,0 \pm 1,1 \\
p>0,05\end{array}$ & $12,0 \pm 1,0$ & $\begin{array}{l}13,0 \pm 1,2 \\
p>0,05\end{array}$ & $13,0 \pm 1,1$ & $\begin{array}{l}14,0 \pm 0,9 \\
p>0,05\end{array}$ \\
\hline Поверхнева стегнова & $7,0 \pm 0,6$ & $\begin{array}{l}7,0 \pm 0,7 \\
p>0,05\end{array}$ & $7,0 \pm 0,5$ & $\begin{array}{l}8,0 \pm 0,7 \\
p>0,05\end{array}$ & $8,0 \pm 0,9$ & $\begin{array}{l}9,0 \pm 1,0 \\
p>0,05\end{array}$ \\
\hline Велика підшкірна & $4,0 \pm 0,5$ & $\begin{array}{l}5,0 \pm 0,6 \\
p>0,05\end{array}$ & $5,0 \pm 0,5$ & $\begin{array}{l}6,0 \pm 0,7 \\
p>0,05\end{array}$ & $5,0 \pm 0,6$ & $\begin{array}{l}6,0 \pm 0,5 \\
p>0,05\end{array}$ \\
\hline Підколінна & $6,0 \pm 0,5$ & $\begin{array}{l}7,0 \pm 0,5 \\
p>0,05\end{array}$ & $6,0 \pm 0,7$ & $\begin{array}{l}7,0 \pm 0,6 \\
p>0,05\end{array}$ & $7,0 \pm 0,5$ & $\begin{array}{l}8,0 \pm 0,6 \\
p>0,05\end{array}$ \\
\hline
\end{tabular}

Таблиця 2. Показники діаметра вен нижніх кінцівок (мм) у хворих із супутньою варикозною хворобою вен нижніх кінцівок до та після ЛХЕ

\begin{tabular}{|c|c|c|c|c|c|c|}
\hline \multirow{3}{*}{$\begin{array}{c}\text { Обстежувана } \\
\text { вена }\end{array}$} & \multicolumn{6}{|c|}{ Хронічний калькульозний холецистит + варикозна хвороба вен нижніх кінцівок } \\
\hline & \multicolumn{2}{|c|}{$\begin{array}{c}\text { XВН - I ст. } \\
(\mathrm{n}-14)\end{array}$} & \multicolumn{2}{|c|}{$\begin{array}{c}\text { XBH - II ст. } \\
(\mathrm{n}-10)\end{array}$} & \multicolumn{2}{|c|}{$\begin{array}{c}\text { XBH - III ст. } \\
(\mathrm{n}-2)\end{array}$} \\
\hline & до ЛХЕ & після ЛХЕ & до ЛХЕ & після ЛХЕ & до ЛХЕ & після ЛХЕ \\
\hline Загальна стегнова & $13,0 \pm 1,1$ & $\begin{array}{l}14,0 \pm 1,2 \\
p>0,05\end{array}$ & $14,0 \pm 1,0$ & $\begin{array}{l}16,0 \pm 1,3 \\
p>0,05\end{array}$ & $14,0 \pm 1,2$ & $\begin{array}{l}16,0 \pm 1,1 \\
p>0,05\end{array}$ \\
\hline Поверхнева стегнова & $8,0 \pm 0,7$ & $\begin{array}{l}9,0 \pm 1,0 \\
p>0,05\end{array}$ & $9,0 \pm 0,9$ & $\begin{array}{l}10,0 \pm 1,0 \\
p>0,05\end{array}$ & $8,0 \pm 0,9$ & $\begin{array}{l}10,0 \pm 0,8 \\
p>0,05\end{array}$ \\
\hline Підколінна & $8,0 \pm 0,5$ & $\begin{array}{l}9,0 \pm 0,7 \\
p>0,05\end{array}$ & $9,0 \pm 0,6$ & $\begin{array}{l}10,0 \pm 1,0 \\
p>0,05\end{array}$ & $9,0 \pm 0,8$ & $\begin{array}{l}10,0 \pm 0,9 \\
p>0,05\end{array}$ \\
\hline
\end{tabular}


не, тони серця чисті, ритмічні, артеріальний тиск 140/80 мм рт. ст., частота серцевих скорочень 78 уд/хв. Язик вологий. Передня черевна стінка бере участь в акті дихання. Живіт при пальпації м'який, помірно болючий в правому підребер'ї. Позитивні симптоми Ортнера, Мерфі. Симптом Щоткіна-Блюмберга негативний. Печінка збільшена на 3 см, її край м'який, заокруглений, неболючий. Перистальтика кишечника задовільна, гази відходять, фізіологічні відправлення в нормі.

При огляді правої та лівої нижніх кінцівок по внутрішній поверхні в ділянці стегна та гомілки виявлено розширення поверхневих вен за змішаним типом; помірний набряк гомілки.

Проведено УЗД органів черевної порожнини та виявлено, що печінка помірно збільшена, гомогенна, внутрішньопечінкові жовчні протоки не розширені. Жовчний міхур об'ємом 351 см³ , гіпотонічний, овальної форми зі стінками завтовшки 7 мм, по задній стінці візуалізується конкремент 22 мм. Холедох не розширений, 6 мм, вільний. Підшлункова залоза не збільшена.

Після доплерівського обстеження судин відмічено, що поверхневі та глибокі вени прохідні. Визначається ретроградний кровотік у поверхневих венах. Діаметр стегнової вени на рівні середньої третини стегна, 14 мм.

Хвора направлена на загальний та біохімічний аналізи крові. Дані лабораторного дослідження: лейкоцити 9,6 ×10\% л, паличкоядерні - 9, сегментоядерні - 48, лімфоцити - 29, моноцити - 11, еозинофіли - 2, базофіли - 1, ШОЕ - 25 мм/год.

Результати біохімічного аналізу крові показали білірубін на рівні - 31,2 мкмоль/л (прямий -19,5 мкмоль/л, непрямий - 11,7 мкмоль/л), АсАТ - 0,54 мкмоль/л год, АлАТ - 0,67 мкмоль/ год, амілаза - 44 г/л год, сечовина - 5,26 ммоль/л.

Дані гемостазіограми: АЧТЧ - 26,2 с, ПЧ 18,6 с, час згортання крові - 5,5 хв, фібриноген 4,0 г/л.

Проведено визначення вмісту ендотеліну-1 (1,41 фмоль/л) та фактора Віллебранда (ф.VIII) $68,2 \%$.

На основі скарг пацієнта, анамнезу захворювання та даних лабораторно-інструментальних методів обстеження було встановлено діагноз: хронічний калькульозний холецистит, фаза загострення. Емпієма жовчного міхура. Варикозна хвороба обох нижніх кінцівок. XBН II ст. IXC. Атеросклеротичний кардіосклероз, неповна блокада правої ніжки пучка Гіса. СН-I ст.

Гістологічне дослідження підтвердило наявність хронічного запалення стінки жовчного міхура.
На наступний день після госпіталізації проведено операційне втручання: сафенектомію за Трояновим-Тренделенбургом, Бебкоком, Наратом. Симультанно - лапароскопічна холецистектомія. Дренування черевної порожнини.

При доплерівському обстеженні судин глибокі вени прохідні, кровотік не порушений. Рефлюксу крові немає. Діаметр стегнової вени на рівні середньої третини, 16 мм.

Результати гемостазіограми після операційного втручання становили: АЧТЧ - 21,9 с, ПЧ - 12,5 с, час згортання крові - 3,3 хв, фібриноген - 4,3 г/л. При аналізі гемостазіограми даної хворої видно, що після симультанної операції виникає значно більша загроза розвитку тромбозу, яка проявляється вираженими ознаками гіперкоагуляції. Вміст ендотеліну-1 становить 2,88 фмоль/л, фактор Віллебранда (ф.VIII) $293,1 \%$. У хворої відмічається значне зростання (майже у 2 рази) вмісту ендотеліну-1 та фактора Віллебранда після проведеної холецистектомії та сафенектомії, що є ознакою вираженої ендотеліальної дисфункції.

У післяопераційному періоді проводили адекватне знеболювання, призначали антикоагулянти, антибактеріальні препарати, венотоніки. Проводили корекцію водно-електролітного обміну. Виконували щоденні асептичні перев'язки та еластичне бинтування нижніх кінцівок. Дренажі з черевної порожнини забрано на 2-у добу. Шви з ділянки післяопераційної рани живота зняли на 7-у добу, в ділянці нижньої кінцівки через один - на 8-у, всі на десяту добу після операції. Всі рани загоїлись первинним натягом.

На 10-й день лікування хвору у задовільному стані виписали.

Висновки. Проведені обстеження підтвердили необхідність операційного втручання з приводу варикозної хвороби вен нижніх кінцівок у хворих із хронічним калькульозним холециститом, що є необхідним з метою профілактики розвитку в післяопераційному періоді тромбозу, а відтак, можливої в подальшому тромбоемболії легеневої артерії.

Перспективи подальших досліджень. Обгрунтованим $\epsilon$ перспектива подальшого морфологічного дослідження венозної стінки у хворих 3 хронічним калькульозним холециститом, поєднаним із варикозною хворобою вен нижніх кінцівок та інших маркерів ендотеліальної дисфункції в дота післяопераційному періодах. 


\section{З ДОСВІДУ РОБОТИ}

\section{СПИСОК ЛІТЕРАТУРИ}

1. Интраоперационная холангиография при выполнении лапароскопической холицистэктомии / М. А. Каштальян, В. Ю. Шаповалов, О. Б. Тымчук // Клінічна хірургія. - 2009. - № 7-8. - С. 56-58.

2. Кисляков В. В. Об опасностях и осложнениях лапароскопической холицистэктомии / В. В. Кисляков, Э. Б. Усеинов, К. Л. Гройзик // Харківська хірургічна школа. - 2009. - № 4. 1 (36). - С. 207-209.

3. Профілактика тромбоемболічних ускладнень при лапароскопічних операціях на жовчних шляхах / Л. Я. Ковальчук, I. К. Венгер, О. Л. Ковальчук, В. Д. Гощинський [та ін.] // Шпитальна хірургія. - 2006. - № 4. - С. 81-83.

4. Віддалені результати лапароскопічної холецистектомії / О. В. Костирной, О. К. Бабалич, А. А. Древетняк [та ін.] // Харківська хірургічна школа. - 2009. - № 4.1 (36). - С. 219-221.

5. Магдиев Т. Ш. Сочетанные операции в абдоминальной хирургии / Т. Ш. Магдиев, Н. В. Северинко // Хирургия. 1999. - № 6. - С. 54-56.

6. Майстренко М. А. Желчнокаменная болезнь у лиц пожи-

\section{REFERENCES}

1. Kashtalyan, M.A., Shapovalov, V.Yu., Tymchuk, O.B., \& Pavlishin V.V. (2009). Intraoperatsyonnaya kholangiografiya pri vypolnenii laparoskoiycheskoy kholitsistektomii [Intraoperative cholangiography during laparoscopic cholecystectomy]. Klinichna khirurhiia - Clinical Surgery, 7-8, 56-58 [in Ukrainian].

2. Kyslyakov, V.V., Useinov, E.B., \& Groyzik, K.L. (2009). Ob opasnostyakh i oslozhneniyakh laparoskopicheskoy kholitsistektomii [On the dangers and complications of laparoscopic cholecystectomy]. Kharkivska khirurhichna shkola - Kharkiv Surgical School, 4.1 (36), 207-209 [in Russian].

3. Kovalchuk, L.Ya., Venher, I.K., Kovalchuk, O.L., Hoshchynskyi V.B., Bedeniuk, A.D., Kostiv, S.Ya., \& Duts, S.I. (2006). Profilaktyka tromboembolichnykh uskladnen pry laparoskopichnykh operatsiiakh na zhovchnykh shliakhakh [Prevention of thromboembolic complications in laparoscopic operations on the biliary tract]. Shpytalna khirurhiia - Hospital Surgery, 4, 81-83 [in Ukrainian].

4. Kostyrnoi, O.V., Babalych, O.K., Drevetniak, A.A., \& Shestopalov, D.V. (2009). Viddaleni rezultaty laparoskopichnoi kholetsystektomii [Long-term results of laparoscopic cholecystectomy]. Kharkivska khirurhichna shkola - Kharkiv Surgical School, 4.1 (36), 219-221 [in Ukrainian].

5. Magdiyev, T.G., \& Severinko, N.V. (1999). Sochetannye operatsii $\mathrm{v}$ abdominalnoy khirurgii [Combined surgery in abdominal surgery]. Khirurgiya - Surgery, 6, $54-57$ [in Russian]. 6. Maystrenko, M.A., Dovganyuk V.S., \& Faktonin, A.A. (2007). Zhelchnokamennaya bolezn u lits pozhylogo i starcheskogo лого и старческого возраста: критерии выбора рациональной хирургической практики / Н. А. Майстренко, В. С. Довганюк, А. А. Фактонин // Ендоск. хірургія. - 2007. - № 1. - С. 122-123. 7. Симультанні операції в лапароскопічній хірургії. Наш досвід та перспективи / М. Ю. Ничитайло, А. В. Скумс, В. В. Дяченко // Шпитальна хірургія. - 2004. - № 2. - С. 10-13.

8. Метод електрозварювання біологічних тканин під час виконання лапароскопічних втручань на органах гепатопанкреатодуоденальної зони / М. Ю Ничитайло, О. М. Литвиненко, В. В. Чорний // Клінічна хірургія. - 2008. - № 8. - С. 37-39.

9. Діагностично-лікувальна тактика з використанням мініінвазивних технологій при механічній жовтяниці, зумовленій холедохолітіазом / М. Ю. Ничитайло, Ю. М. Захараш, П. В. Огородник, М. П. Захараш // Хірургія України. - 2008. - № 2 (26). - C. 5-13.

10. Погорелова О. А. Дуплексное сканирование в оценке функции эндотелия на фоне медикоментозных воздействий / О. А. Погорелова // Визуализация в клинике. - 2000. - № 6. - C. $11-16$

vozrasta: kriterii vybora ratsionalnoy khirurgicheskoy praktiki [Gallstone disease in elderly and old people: criteria for choosing a rational surgical practice]. Endosk. Khirurhiia - Endoscopic Surgery, 1, 122-123 [in Russian].

7. Nychytaylo, M.Yu., Skums, A.V., Diachenko, V.V., \& Lytvynenko, O.M. (2004). Symultanni operatsii v laparoskopichnii khirurhii. Nash dosvid ta perspektyvy [Concomitant operations in laparoscopic surgery. Our experience and perspectives]. Shpytalna khirurhiia - Hospital Surgery, 2, 10-13 [in Ukrainian]. 8. Nychytaylo, M.Yu., Lytvynenko, O.M., Chornyi, V.V., \& Hulko, O.M. (2008). Metod elektrozvariuvannia biolohichnykh tkanyn pid chas vykonannia laparoskopichnykh vtruchan na orhanakh hepatopankreatoduodenalnoi zony [Method of electric welding of biological tissues during laparoscopic interventions on the organs of the hepatopancreatoduodenal zone]. Klinichna khirurhiia - Clinical Surgery, 8, 37-39 [in Ukrainian].

9. Nychytaylo, M.Yu., Zakharash, Yu.M., Ohorodnyk, P.V., \& Zakharash, M.P. (2008). Diahnostychno-likuvalna taktyka z vykorystanniam miniinvazyvnykh tekhnolohii pry mekhanichnii zhovtianytsi, zumovlenii kholedokholitiazom [Diagnostic and therapeutic tactics with the use of minimally invasive technologies for mechanical jaundice due to choledocholithiasis]. Khirurhiia Ukrainy - Surgery of Ukraine, 2 (26), 5-13 [in Ukrainian].

10. Pohorelova, O.A. (2000). Dupleksne skanuvannia pry otsintsi funktsii endoteliiu na tli medyomotohennykh efektiv [Duplex scan in the evaluation of endothelium function against the background of mediomotogenic effects]. Vizualizatsiia $v$ klinitsi - Visualization at the Clinic, 6, 11-16 [in Ukrainian]. 
D. B. FIRA

I. Horbachevsky Ternopil State Medical University

\title{
DIAGNOSTIC CRITERIA FOR PREDICTION OF POSSIBLE COMPLICATIONS IN PATIENTS WITH CHRONIC GALCULOUS GHOLECYSTITIS AND CONCOMITANT PATHOLOGY OF LOWER EX- TREMITIY VEINS
}

\begin{abstract}
The aim of the work: to study the state of homeostasis of the body during and after the implementation of minimally invasive surgical interventions, which will allow the development of a pathogenetically substantiated correction of possible disorders.

Materials and Methods. Patients with chronic calculous cholecystitis and pathology of the veins of the lower extremities in the preoperative period were subjected to a complex of diagnostic instrumental-laboratory methods of examination that included laboratory studies with biochemical blood analysis, sonography of the pancreatohepatobiliary zone, retroperitoneal space and fibrogastroduodenoscopy. For an objective assessment of the state of homeostasis, the indices of each individual patient were evaluated, and then the total result was determined.

Results and Discussion. It is established that the cholecystitis clinic is accompanied by a pronounced polymorphism, and the generally accepted indicators of the inflammatory process do not coincide with the registered pathological changes. Based on the results of the study, the expediency of corrective drug therapy in patients after laparoscopic cholecystectomy for more than 90 minutes is justified in the postoperative period. In 26 patients among the 130 diagnosed with concomitant pathology - varicose veins of the lower extremities. We noted that in patients admitted to the hospital with a diagnosis of chronic calculous cholecystitis, with duplex scanning of the veins of the lower limbs, there was an insignificant expansion of the diameter of deep and superficial veins after laparoscopic cholecystectomy. In patients with concomitant pathology of the veins of the lower extremities in the postoperative period, the results obtained with duplex scanning of the veins were most pronounced, which led to both preoperative and postoperative measures to prevent thromboembolic complications and perform simultaneous surgical interventions. The results confirmed the need for surgical intervention for varicose veins of the lower limbs in patients with chronic calculous cholecystitis, which is necessary for the prevention of development in the postoperative period of thrombosis, and then possible later pulmonary embolism.
\end{abstract}

Key words: cholecystitis; varicose veins; simultaneous interventions; clinical and instrumental methods of research; duplex scanning of veins.

Д. Б. ФИРА

ГВУЗ “Тернопольский государственный медицинский университет имени И. Я. Горбачевского МЗ Украины”

\section{ДИАГНОСТИЧЕСКИЕ КРИТЕРИИ ПРОГНОЗИРОВАНИЯ ВОЗМОЖНЫХ ОС.ЛОЖНЕНИЙ У БОЛЬНЫХ С ХРОНИЧЕСКИМ КАЛЬКУЛЕЗНЫМ ХОЛЕЦИСТИТОМ И СОПУТСТВУЮЩЕЙ ПАТО.ЛОГИЕЙ ВЕН НИЖНИХ КОНЕЧНОСТЕЙ}

\begin{abstract}
Цель работы: исследовать состояние гомеостаза организма во время и после выполнения малоинвазивных оперативных вмешательств, что позволит выработать патогенетически обоснованную коррекцию возможных нарушений.

Материалы и методы. Больным с хроническим калькулезным холециститом и патологией вен нижних конечностей в дооперационный период проводился комплекс диагностических инструментально-лабораторных методов обследования, который включает лабораторные исследования с биохимическим анализом крови, сонографию панкреатогепатобилиарной зоны, забрюшинного пространства и фиброгастродуоденоскопию. Для объективной оценки состояния гомеостаза оценивались показатели у каждого отдельного больного, а затем определялся суммарный результат.

Результаты исследований и их обсуждение. Установлено, что клиника холецистита сопровождается выраженным полиморфизмом, причем общепринятые индикаторы воспалительного процесса не совпадают с зарегистрированными патологическими изменениями. На основании результатов исследования обоснована целесообразность применения в послеоперационном периоде у больных после ЛХЕ продолжительностью более 90 мин корректирующей медикаментозной терапии.

У 26 больных из 130 диагностировали сопутствующую патологию - варикозную болезнь вен нижних конечностей. Нами отмечено, что у пациентов, поступивших в стационар с диагнозом хронический калькулезный холецистит, при дуплексном сканировании вен нижних конечностей наблюдалось незначительное расширение диаметра глубоких и поверхностных вен после проведения лапароскопической холецистэктомии. У больных с сопутствующей патологией вен нижних конечностей в послеоперационном периоде полученные результаты при дуплексном сканировании вен были наиболее выражены, что обусловило проведение как в предоперационном, так и в послеоперационном периоде соответствующих мер по профилактике тромбоэмболических осложнений и выполнения симультанных оперативных вмешательств. Полученные результаты подтвердили необходимость оперативного вмешательства по поводу варикозной болезни вен нижних конечностей у больных с хроническим калькулезным холециститом, что необходимо с целью профилактики развития в послеоперационном периоде тромбоза, а затем возможной в дальнейшем тромбоэмболии легочной артерии.
\end{abstract}

Ключевые слова: холецистит; варикозная болезнь; симультанные вмешательства; клинико-инструментальные методы исследования; дуплексное сканирование вен. 